\title{
Adolescent Exposure to Food Advertising on Television
}

\section{POLICY PERSPECTIVE}

TEENS ARE A FAST-GROWING

CONSUMER MARKET, SPENDING

APPROXIMATELY \$159 BILLION

ANNUALLY, 21 PERCENT OF

WHICH IS ON FOOD AND

BEVERAGES. ${ }^{1}$ IN ADDITION TO

BUYING FOOD WITH THEIR OWN

MONEY, THREE-QUARTERS OF

ADOLESCENTS DIRECTLY

INFLUENCE FAMILY FOOD

PURCHASES. RESEARCH

SHOWS A LINK BETWEEN

EXPOSURE TO FOOD

ADVERTISING AND TEENS'

WEIGHT STATUS. POLICIES

THAT ENCOURAGE THE FOOD

INDUSTRY TO CHANGE THEIR

MARKETING PRACTICES ARE

IMPORTANT TO REVERSING THE

CHILDHOOD OBESITY EPIDEMIC.

\section{Background}

O ver the past few decades, the number of overweight adolescents in the United States has tripled. Currently, one-third (33.6\%) of all children and adolescents in the United States are either overweight or obese. This alarming trend is even more pronounced among minority populations. Previous research identified changes in leisure-time activities, such as lack of physical activity and increased time spent watching television (and televised food advertising), as contributors to this epidemic. A report by the Institute of Medicine concluded that there is strong evidence linking exposure to television advertising to obesity in children and adolescents. ${ }^{2}$ Children and adolescents watch on average 3 hours and 19 minutes a day of television, ${ }^{3}$ making research on food advertising exposure a priority for understanding and addressing the childhood obesity epidemic.

In a series of studies funded by the Robert Wood Johnson Foundation (RWJF), Dr. Lisa Powell and colleagues at the University of Illinois at Chicago used television program ratings to examine food advertising exposure and the nutritional content of the foods advertised on programs viewed by adolescents ages 12-17. Study results appear in the September 2007 issue of Pediatrics ${ }^{4}$ and in an October 2007 RWJF-funded supplement of the American Journal of Preventive Medicine ${ }^{5}$ focused on policy and environmental strategies for reversing the youth obesity epidemic. Previous research on food advertising exposure has focused predominately on content analyses, a method that counts all ads aired on television. These studies extend that research by linking program ratings data to data about the advertisements aired, the nutritional content of the products advertised, and thus actual exposure of adolescents to ads for healthy and unhealthy foods as defined by USDA nutrition standards. In addition, the studies provide unique data on ad exposure among teens in varied racial/ethnic populations.

\section{Key Findings}

- Food and beverage ads commonly seen by adolescents promote products high in calories and low in nutritional value. Most of the food product advertisements $(89.4 \%)$ viewed by adolescents were for foods high in fat, sugar or sodium.

Nearly half (49.1\%) of the total calories for the products advertised to adolescents came from sugar. A higher proportion of food advertisements seen by African Americans (see Chart, page 2) were for high-sugar products compared with those viewed by white adolescents.

1 Teenage Research Unlimited (2005) The TRU Study. Available at URL: http://wrew.teenresearch.com/PRview.cfm?edit_id=378

2 Institute of Medicine. Food Marketing to Children and Youth: Threat or Opportunity? Washington, DC: National Academies Press; 2006. Report is available at: bttp://wrerw.iom.edu/sid $=31330$ eredirect $=0$

3 Institute of Medicine. Food Marketing to Children and Youth: Threat or Opportunity? Washington, DC: National Academies Press; 2006. Report is available at: http://wrewe.iom.edu/ $i d=31330$ eredirect $=0$

4 Powell LM, Szczypka G, Chaloupka FJ and Braunschweig CL. "Nutritional Content of Television Food Advertisements Seen by Children and Adolescents in the United States.” Pediatrics, 120 (3): 576-583, September 2007. Article available at: bttp://pediatrics.aappublications.org/cgi/content/abstract/120/3/576.

5 Powell LM, Szczypka G and Chaloupka FJ. “Adolescent Exposure to Food Advertising on Television.” American Journal of Preventive Medicine, 33(4) Supplement 1, S251-S256, October 2007. Article available at: http://wewwerwif.org/pr/product.jsp? $i d=22272$

1 RWJF Research Highlight-Adolescent Exposure to Food Advertising on Television 


\begin{tabular}{lcccccc}
\hline \multicolumn{7}{l}{ Nutritional Content of Food Product Advertisements Seen by Adolescents } \\
\hline & All Foods & Gereal & Sweets & Snacks & Drinks & Other \\
& $\%$ & $\%$ & $\%$ & $\%$ & $\%$ & $\%$ \\
\hline High fat & 25.3 & 0.0 & 46.3 & 45.1 & 0.5 & 28.9 \\
High saturated fat & 26.4 & 0.5 & 51.6 & 23.5 & 2.0 & 38.7 \\
High sugar & 74.1 & 93.9 & 82.4 & 41.2 & 94.4 & 34.1 \\
High sodium & 8.2 & 2.7 & 0.2 & 0.1 & 0.9 & 45.2 \\
Low fiber & 77.1 & 72.0 & 69.4 & 84.0 & 98.8 & 62.0 \\
Either high fat or high sugar & 85.1 & 93.9 & 86.3 & 84.2 & 94.4 & 62.1 \\
Either high fat, sugar or sodium & 89.4 & 93.9 & 86.3 & 84.3 & 94.4 & 87.7
\end{tabular}

- Adolescents spend a significant proportion of time watching food advertisements. Approximately one-fifth (19.6\%) of all national advertising exposure for adolescents ages $12-17$ is food-related (20.4\% for African Americans and $18.7 \%$ for whites). Food-related advertisements include food products and restaurant and fast-food offerings. Other advertisements assessed in this study include non-food products, public service announcements and TV promotions.

- TV-viewing patterns and resulting exposure to food advertising differ by race. The proportion of advertisements viewed for food products is 14 percent greater for African-American versus white adolescents. Total exposure to food advertising would be even larger for African American teens given that, on average, they watch more TV (40 percent more during prime time and 95 percent more during the daytime).

- Fast food is the most frequently viewed food category seen by white and African-American adolescents. Nearly one-quarter of food advertisements (23\%) seen were for fast-food restaurants, and ads for fast-food restaurants were viewed differently by race.

Distribution of Advertising Exposure by Food Products Among Adolescents Ages 12 to 17

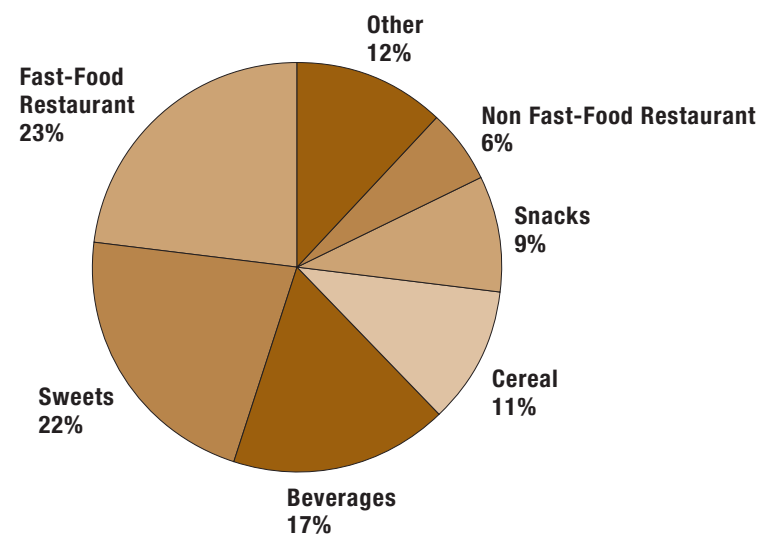

-Stephanie Weiss Stephanie Weiss is a Robert Wood Johnson Foundation Research Associate. 